\title{
Communication
}

\section{The Novel Benzothiazole Derivative PB11 Induces Apoptosis via the PI3K/AKT Signaling Pathway in Human Cancer Cell Lines}

\author{
Jinsun Kim ${ }^{1}\left(\mathbb{D}\right.$, Sung Hee Hong ${ }^{2}$, So Hyun Jeon ${ }^{1}$, Min Ho Park ${ }^{1}$ and Cha-Gyun Shin ${ }^{1, *}$ \\ 1 Department of Systems Biotechnology, Chung-Ang University, Ansung 17546, Korea; \\ adkan4@naver.com (J.K.); wjsthgus0309@daum.net (S.H.J.); minho089@hanmail.net (M.H.P.) \\ 2 Division of Radiation Biomedical Research, Korea Institute of Radiological and Medical Sciences, \\ Seoul 139-706, Korea; gobrian@kcch.re.kr \\ * $\quad$ Correspondence: cgshin@cau.ac.kr; Tel.: +82-31-670-3067
}

Citation: Kim, J.; Hong, S.H.; Jeon, S.H.; Park, M.H.; Shin, C.-G. The Novel Benzothiazole Derivative PB11 Induces Apoptosis via the PI3K/AKT Signaling Pathway in Human Cancer Cell Lines. Int. J. Mol. Sci. 2021, 22, 2718. https://doi.org/10.3390/ ijms 22052718

Academic Editor: Ahmad R. Safa

Received: 3 February 2021

Accepted: 4 March 2021

Published: 8 March 2021

Publisher's Note: MDPI stays neutral with regard to jurisdictional claims in published maps and institutional affiliations.

Copyright: (c) 2021 by the authors. Licensee MDPI, Basel, Switzerland. This article is an open access article distributed under the terms and conditions of the Creative Commons Attribution (CC BY) license (https:/ / creativecommons.org/licenses/by/ $4.0 /)$.

\begin{abstract}
Among several anti-cancer therapies, chemotherapy can be used regardless of the stage of the disease. However, development of anti-cancer agents from potential chemicals must be executed very cautiously because of several problems, such as safety, drug resistance, and continuous administration. Most chemotherapeutics selectively cause cancer cells to undergo apoptosis. In this study, we tested the effects of a novel chemical, the benzothiazole derivative N-[2-[(3,5-dimethyl-1,2oxazol-4-yl)methylsulfanyl]-1,3-benzothiazol-6-yl]-4-oxocyclohexane-1-carboxamide (PB11) on the human cell lines U87 (glioblastoma), and HeLa (cervix cancer). It was observed that this chemical was highly cytotoxic for these cells (IC50s < $50 \mathrm{nM}$ ). In addition, even $40 \mathrm{nM}$ PB11 induced the classical apoptotic symptoms of DNA fragmentation and nuclear condensation. The increase of caspase-3 and -9 activities also indicated an increased rate of apoptosis, which was further confirmed via Western blotting analysis of apoptosis-associated proteins. Accordingly, PB11 treatment up-regulated the cellular levels of caspase-3 and cytochrome-c, whereas it down-regulated PI3K and AKT. These results suggest that PB11 induces cytotoxicity and apoptosis in cancer cells by suppressing the PI3K/AKT signaling pathways and, thus, may serve as an anti-cancer therapeutic.
\end{abstract}

Keywords: apoptosis; human cancer cells; novel chemical

\section{Introduction}

For half a century, cancer patients have received three primary medical treatmentssurgery, chemotherapy, and radiation therapy. Among these treatments, chemotherapy has the advantage of being applicable regardless of cancer stage. Over time, enormous medical progress has been made in understanding cancer biology and targeted chemotherapeutics [1-4]. New therapeutic chemicals and approaches with potent effects on tumor or healthy tissues are constantly being introduced into the clinic [5]. It is now increasingly accepted that the effectiveness of conventional chemotherapeutic drugs is in part due to their ability to induce apoptosis, although this area is not without controversy [6,7].

Benzothiazole derivatives are heterocyclic compounds with oxygen, nitrogen, and sulfur in their structures [8,9]. They have wide ranges of bioactivities, such as anti-diabetic [10], anti-microbial [11], anti-inflammatory [12], anti-fungal [13], and anti-neoplastic activities $[14,15]$. Recently, new diverse compounds synthesized using the rational drug designing approaches have been reported to have remarkable effects as anti-cancer drugs [16-18]. These compounds target the regulatory pathways of various biological events and critical factors that are essential for the survival of cancer cells. These targets include DNA replication, transcription, translation, and mitosis [19].

Recently, SH Hong and his colleagues, one of our authors, reported several potential anti-cancer compounds that have been selected from a chemical library obtained from the 
ChemBridge (San Diego, CA, USA) [20-22]. Several candidates were obtained from the library screening. Benzothiazole derivative is one of the candidates from above. In this study, a novel benzothiazole derivative, $\mathrm{N}$-[2-[(3,5-dimethyl-1,2-oxazol-4-yl)methylsulfanyl]-1,3benzothiazol-6-yl]-4-oxocyclohexane-1-carboxamide (PB11), was tested for potential use as an anticancer compound (Figure 1). By targeting the apoptosis pathway with the aim of inducing cytotoxicity, experiments were designed and conducted on human cancer cell lines U87 and HeLa.

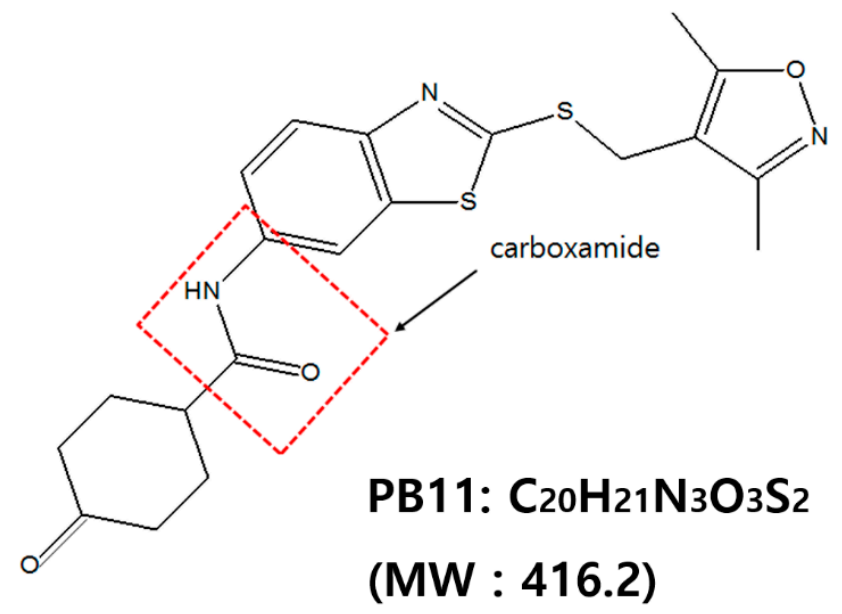

Figure 1. Chemical structure of N-[2-[(3,5-dimethyl-1,2-oxazol-4-yl)methylsulfanyl]-1,3-benzothiazol6-yl]-4-oxocyclohexane-1-carboxamide (PB11, MW: 416.2).

\section{Results and Discussion}

\subsection{PB11 Is Highly Cytotoxic at the nM Scale}

First, cytotoxicity of PB11 was investigated with both non-cancer cell lines and cancer cell lines. It was shown that PB11 is less cytotoxic to non-cancer cells compared to cancer cell lines [Data not shown]. Among the cancer cell lines tested, the viabilities of U87 and HeLa cells were significantly reduced in the presence of PB11, as assessed via the 2,5diphenyl tetrazolium bromide (MTT) and lactate dehydrogenase (LDH) assays (Figure 2). In the case of U87 cells, treatment with $10 \mathrm{nM}, 100 \mathrm{nM}, 1 \mu \mathrm{M}$, or $10 \mu \mathrm{M}$ PB11 decreased the cell viability to $85.91 \pm 1.25 \%, 37.25 \pm 4.02 \%, 19.23 \pm 0.78 \%$, and $6.56 \pm 0.15 \%$, respectively, of the untreated control cells. The same concentrations of PB11 decreased the viability of HeLa cells to $86.82 \pm 5.2 \%, 46.23 \pm 2.18 \%, 21.46 \pm 1.42 \%$, and $11.34 \pm 1.03 \%$, respectively, of the untreated control. Based on the dose-response curves, the IC50 for PB11 was estimated to be approximately $40 \mathrm{nM}$ (Figure 2A).

Lactate dehydrogenase (LDH) is a cytosolic enzyme present in many cell types and is released into the media of cell cultures when the plasma membrane is damaged [23]. The LDH cytotoxicity assay is a colorimetric assay that provides a simple and reliable method for determining cytotoxicity. In the case of the U87 cells, the LDH cytotoxicity levels of the cells treated with $0 \mathrm{nM}$ (mock), $10 \mathrm{nM}, 100 \mathrm{nM}, 1 \mu \mathrm{M}$, and $10 \mu \mathrm{M}$ PB11 were $8.41 \pm 0.35 \%$, $24.04 \pm 1.60 \%, 59.90 \pm 0.08 \%, 84.20 \pm 0.70 \%$, and $93.51 \pm 1.04 \%$, respectively, of the control, which was entirely lysed untreated cells (Figure 2B). In addition, the LDH cytotoxicity levels in HeLa cells were $9.27 \pm 0.10 \%, 19.72 \pm 0.97 \%, 60.32 \pm 1.35 \%, 76.68 \pm 1.73 \%$, and $93.88 \pm 0.63 \%$, respectively. As shown in Figure 2, the LDH assay results strongly supported the MTT assay results. Altogether, these results show that PB11 is highly cytotoxic to U87 and HeLa cells at the nM scale. 
A

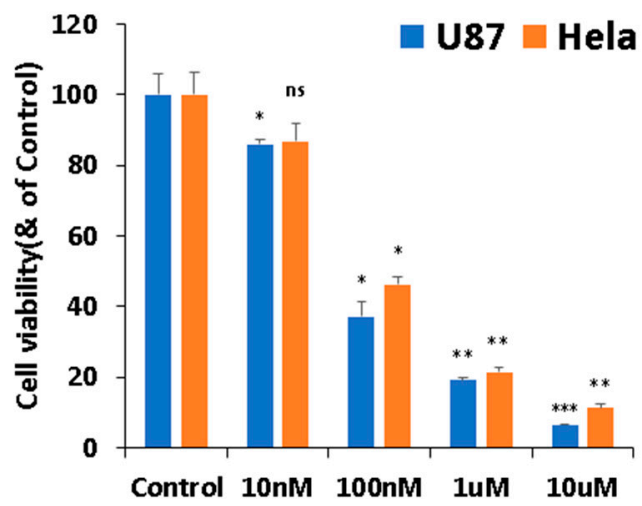

B

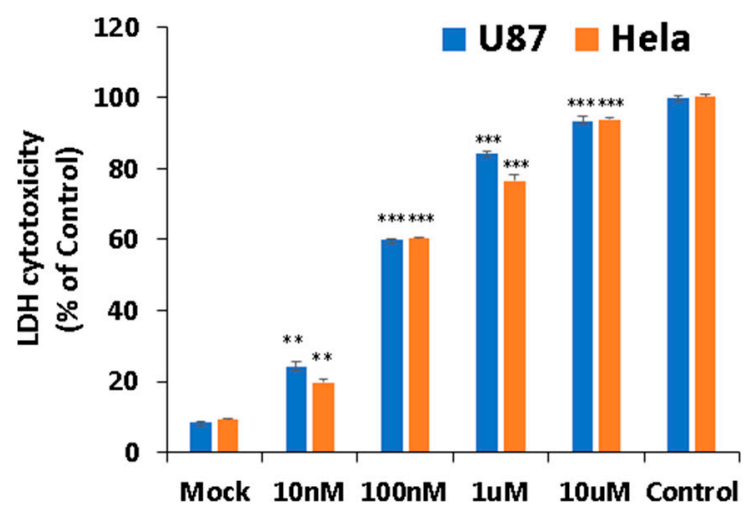

Figure 2. Cell cytotoxicity of PB11 in cancer cells. U87 and HeLa cells were grown in 96-well culture plates with 0 nM, 10 $\mathrm{nM}, 100 \mathrm{nM}, 1 \mu \mathrm{M}$, or $10 \mu \mathrm{M}$ PB11. After $48 \mathrm{~h}$, the cytotoxicity of PB11 was evaluated by determining the number of viable cells via the 2,5-diphenyl tetrazolium bromide (MTT) assay (A) or by determining the amount of lactate dehydrogenase $(\mathrm{LDH})$ released into culture $(\mathbf{B})$. The cell viability and released LDH amount are presented as percentages of the control (mock-treated cells in (A) and lysed untreated cells in (B)). Based on the dose-response curves, the IC50 for PB11 was estimated to be approximately $40 \mathrm{nM}$. All data are expressed as mean $\pm \mathrm{SEM}$. Statistical significance was analyzed with the two-paired Student's $t$-test; ns $=p>0.05,{ }^{*}=p<0.05,{ }^{* *}=p<0.01$, and ${ }^{* *}=p<0.001$.

\subsection{PB11 Induces Apoptosis through Mitochondria}

We hypothesized that the reduced cell number observed upon PB11 treatment might be associated with apoptosis. Therefore, PB11-treated cells were assessed for the classical apoptosis indicators DNA and nuclear fragmentation.

Very distinctive DNA fragmentation was detected in U87 and HeLa cells treated with $40 \mathrm{nM}$ PB11 (Figure 3A). In this experiment, we used $5 \mu \mathrm{M}$ camptothecin, which is a well-known apoptotic drug, as a positive control [24]. PB11 induced DNA fragmentation very clearly and effectively as $40 \mathrm{nM}$ PB11 induced greater DNA fragmentation than $5 \mu \mathrm{M}$ camptothecin.

A

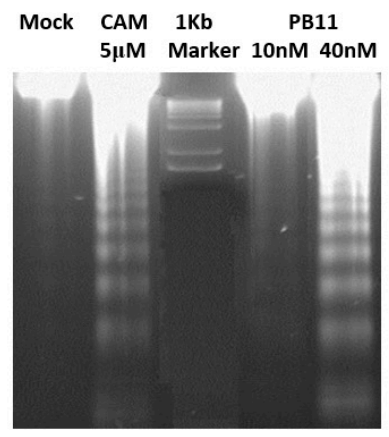

U87

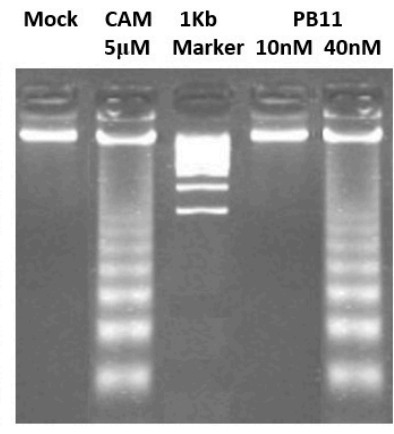

Hela
B

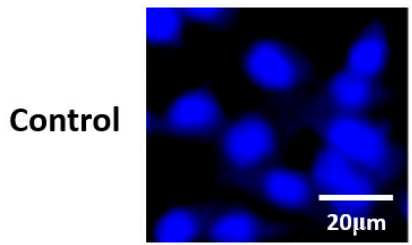

PB11

40nM

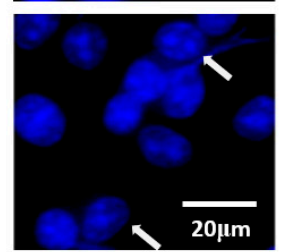

U87
DAPI
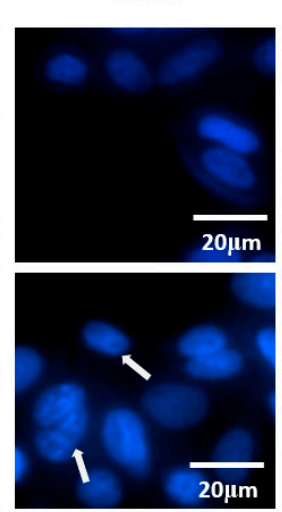

Figure 3. Apoptotic fragmentation of PB11-treated cancer cells. (A) DNA fragmentation. U87 and HeLa cells were grown in 6-well culture plates with 10 or $40 \mathrm{nM}$ PB11. After $48 \mathrm{~h}$, the cells were harvested and lysed. DNA was precipitated by ethanol. As a positive control for DNA fragmentation, cells treated with $5 \mu \mathrm{M}$ camptothecin (CAM) were likewise investigated. (B) Nuclear fragmentation and condensation. Both cells were grown in 8-well culture plates with $40 \mathrm{nM}$ PB11. The cell nucleus was stained using DAPI. Scale bar is denoted in figure. 
Furthermore, DAPI (4',6-diamidino-2-phenylindole) DNA staining revealed that PB11 caused alterations in the nuclear morphologies of U87 and HeLa cells, such as nuclear condensation and fragmentation, which are suggestive of apoptosis (Figure 3B, arrow).

Caspases are recognized as the key enzymes of apoptosis [25]. To investigate whether they are associated with PB11-induced cytotoxicity, the levels of apoptotic markers in PB11treated cells were evaluated (Figure 4A). We observed that the levels of Bax, cytochrome c, and cleaved caspase-3, which is the active form, were increased in PB11-treated cells. These data support our conclusion that PB11 induces cytotoxicity via apoptosis.

A
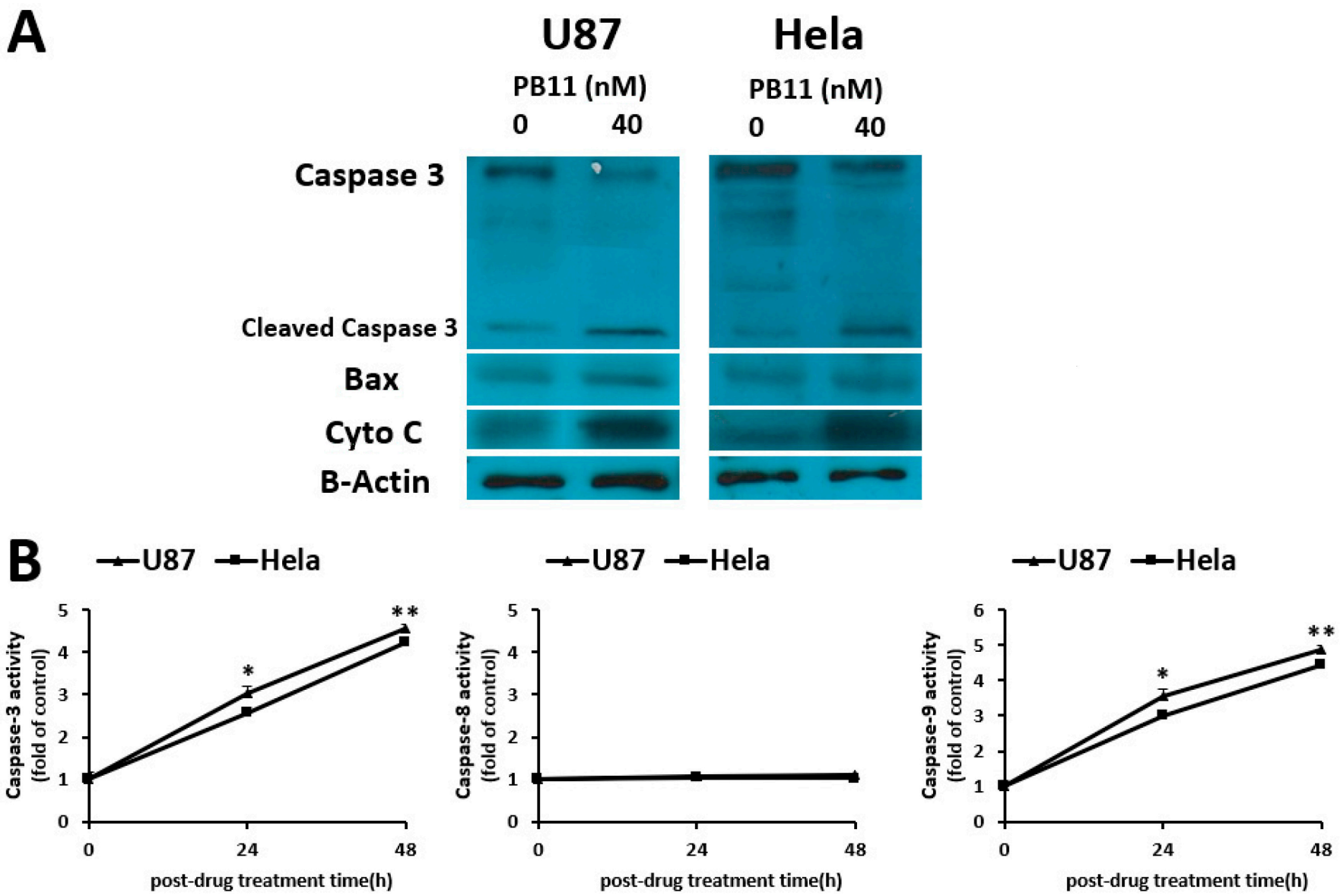

Figure 4. The increased levels of apoptosis markers in PB11-treated cells. (A): Western blot of apoptotic proteins. U87 and HeLa cells were grown in 6-well culture plates with $40 \mathrm{nM}$ PB11. After $48 \mathrm{~h}$, cell lysates were prepared and blotted with antibodies against caspase-3, Bax, and cytochrome C. $\beta$-actin was used as loading control. (B): Comparison of caspase-3, -8 , and -9 activities. Cells were treated with $40 \mathrm{nM}$ PB11. Cell lysates were prepared after $24 \mathrm{~h}$ and $48 \mathrm{~h}$. The caspase activities were assessed using commercial kits. All data are expressed as mean $\pm \mathrm{SEM}$. Statistical significance was analyzed with the two-paired Student's $t$-test; ns $=p>0.05,{ }^{*}=p<0.05,{ }^{* *}=p<0.01$.

Apoptosis occurs via the intrinsic or extrinsic pathway. The intrinsic pathway, also called the mitochondrial pathway, is activated by intracellular signal in intermembrane space of mitochondria, whereas the extrinsic pathway is activated by ligand binding interaction in extracellular surface [26]. To understand which pathway is involved in the apoptotic process of PB11-treated cells, the activities of caspase-3, -8 , and -9 were evaluated by using colorimetric assay (Figure 4B). PB11 treatment of the cells increased the activities of caspase- 3 and -9 by time. After $24 \mathrm{~h}$ and $48 \mathrm{~h}$ treatment, the activities were increased by approximately three- and five-fold, respectively. Conversely, the caspase- 8 activities in the cells were unaffected. Therefore, PB11 seems to induce cytotoxicity via the intrinsic pathway of apoptosis. 


\subsection{PB11 Induces Apoptosis via the PI3K/AKT Signaling Pathway}

To gain further insight into the molecular mechanisms underlying the PB11-induced apoptosis, we decided to screen the expression levels of several signal-transducing proteins, such as PI3K, JNK, and AKT, which are directly related to cell proliferation and death. Hyper-activation of the PI3K/AKT signal-transduction pathway leads to hyperplasia and neoplastic transformation, whereas inhibition of the pathway is frequently associated with cell death [26]. The c-Jun N-terminal kinase (JNK) pathway is involved in cell growth associated with a wide range of abiotic and biotic stresses [27]. The NFKB/IKB pathway is important in regulating cellular physiological and immunological statuses [28].

Western blot analysis for members of these pathways revealed that PB11 treatment decreased the levels of phosphorylated (p-) PI3K and p-AKT, which are the active forms of PI3K and AKT, respectively (Figure 5). Conversely, the levels of active JNK (p-JNK) and $\mathrm{NF} \kappa \mathrm{B}(\mathrm{p}-\mathrm{NF} \kappa \mathrm{B})$ were unaffected. These results indicate that PB11 represses the PI3K/AKT pathway but does not affect the JNK and NFKB pathways, and consequently, the cells undergo apoptosis.

\section{U87 Hela}

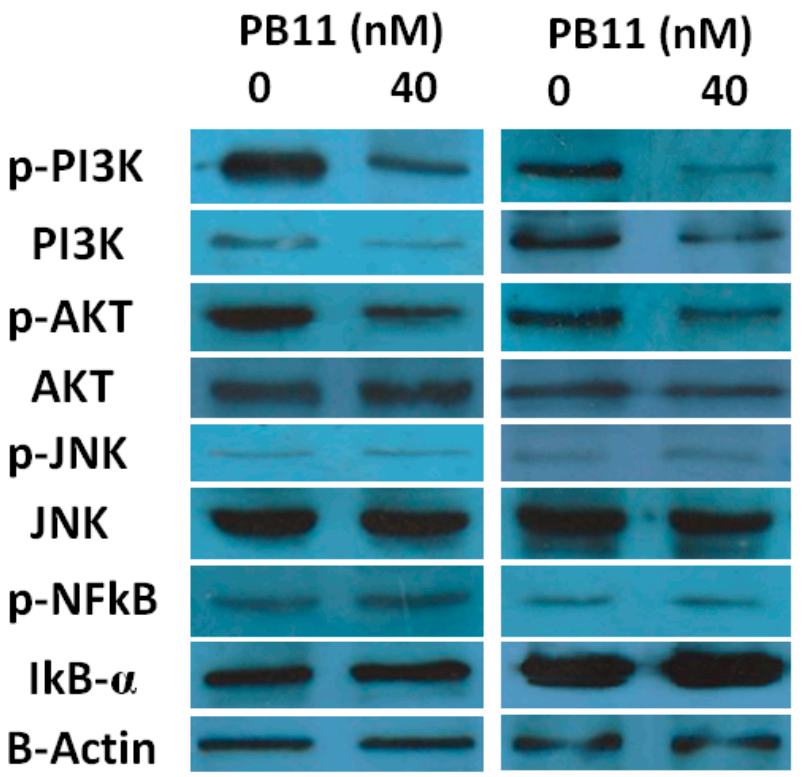

Figure 5. Suppression of the PI3K/AKT pathway by PB11. U87 and HeLa cells were grown in 6-well culture plates with or without $40 \mathrm{nM}$ PB11. After $48 \mathrm{~h}$, cell lysates were prepared and blotted with antibodies against PI3K, p-PI3K, JNK, p-JNK, IKB $\alpha, \mathrm{NF}$ KB p65, AKT, and p-AKT. B-actin was used as a loading control.

Taken together, it is proposed that the novel benzothiazole derivative PB11 may be beneficial for the treatment of several cancers. Additionally, these results support the conclusions of a previous study wherein benzothiazole suppressed the migration and invasion of cancer cells $[17,18,29]$. Furthermore, one of the benzothiazole derivatives containing carboxamide also showed anti-cancer effect to the MCF-7 cell line [30]. Both PB11 and that derivative have high cell cytotoxicity in nM scale. The PI3K/AKT pathway has been shown to be aberrantly activated in several cancer types and is responsible for the emergence, growth, and development of various cancers in humans [31]. Accordingly, it is an important target for the management of cancers in humans. Interestingly, this study found that the novel benzothiazole PB11 suppresses the PI3K/AKT pathway in cancer cells, highlighting the potential of this compound as a therapeutic against various cancers. 


\section{Materials and Methods}

\subsection{Reagents}

PB11 was obtained from Chembridge (San Diego, CA, USA). Each dose of PB11 was prepared by diluting with $40 \%$ dimethyl sulfoxide (DMSO). 2,5-diphenyl tetrazolium bromide (MTT) and DAPI reagents were purchased from Sigma-Aldrich (St. Louis, MO, USA). The LDH assay kit was obtained from Dongin Biotech (Seoul, Korea). Caspase-3 and -9 assay kits were purchased from Promega (Madison, WI, USA), and the caspase8 assay kit from Biovision (Milpitas, CA, USA). The antibodies against Caspase-3, Bax, Cytochrome $\mathrm{C}, \mathrm{I} \kappa \mathrm{B} \alpha, \mathrm{NF} \kappa \mathrm{B}$ p65, JNK, p-JNK, AKT, p-AKT, and PI3K were purchased from Santa Cruz (Santa Cruz, CA, USA). The p-PI3K monoclonal antibody was purchased from Cell Signaling Technology (Danvers, MA, USA). The rabbit anti-B-actin antibody was purchased from Thermo Fisher Scientific (Waltham, MA, USA).

\subsection{Cell Culture}

The human cancer cell lines U87 and HeLa cells (Korean Cell Line Bank, Seoul, Korea) were cultured in Dulbecco's modified Eagle's Medium (DMEM) supplemented with $2 \mathrm{mM}$ L-glutamine, 10\% heat-inactivated fetal bovine serum (Sigma-Aldrich, St. Louis, MO, USA), $100 \mathrm{U} / \mathrm{mL}$ penicillin, and $100 \mu \mathrm{g} / \mathrm{mL}$ streptomycin. All cultures were performed at $37^{\circ} \mathrm{C}$ with $5 \% \mathrm{CO}_{2}$.

\subsection{Cell Viability and Toxicity Tests}

\subsubsection{MTT Assay}

The MTT assay was conducted as previously described [32,33]. Briefly, cells were inoculated in 96-well plates ( $50 \mu \mathrm{L}$ of $4 \times 10^{4}$ cells/well). After $4 \mathrm{~h}, 50 \mu \mathrm{L}$ of fresh medium containing PB11 at the indicated doses was added to each well. After $48 \mathrm{~h}$ of continuous exposure, $50 \mu \mathrm{L}$ of $0.1 \mathrm{mg} / \mathrm{mL}$ MTT solution was added into each well, and the samples were incubated at $37^{\circ} \mathrm{C}$ for $4 \mathrm{~h}$. After discarding the supernatants, the cells were incubated with $200 \mu \mathrm{L}$ of $100 \%(w / v)$ DMSO at $25^{\circ} \mathrm{C}$ for $10 \mathrm{~min}$. The absorbance at $595 \mathrm{~nm}$ was measured using a microplate reader. Three independent experiments were conducted in duplicate at different time points.

\subsubsection{LDH Cytotoxicity Assay}

The LDH assay was conducted using the D-Plus ${ }^{\mathrm{TM}} \mathrm{LDH}$ cell cytotoxicity assay kit (Dongin Biotech, Seoul, Korea). Briefly, $2.5 \times 10^{4}$ cells per well were seeded in 96-well plates. After $24 \mathrm{~h}$ of incubation, PB11 at the indicated doses was added into each well in the final volume of $100 \mu \mathrm{L}$. After $48 \mathrm{~h}$, floating cells in the supernatants were removed using centrifugation at $600 \times g$ for $10 \mathrm{~min}$. Control cells were lysed by adding $10 \mu \mathrm{L}$ lysis buffer before centrifugation. Each supernatant $(10 \mu \mathrm{L})$ was transferred to a new well in a 96-well plate. Finally, $100 \mu \mathrm{L}$ of the LDH reaction mixture (1:50 ratio of WST substrate to $\mathrm{LDH}$ assay buffer) was added, and the samples were incubated at $25^{\circ} \mathrm{C}$ for $30 \mathrm{~min}$. The absorbance at $450 \mathrm{~nm}$ was measured using a microplate reader. Three independent experiments were conducted in duplicate at different time points.

\subsection{Assessment of Apoptosis}

\subsubsection{DNA-Fragmentation Assay}

Low-molecular-weight DNA was extracted from cells as previously described [34]. Cells grown in $100 \mathrm{~mm}$ plates were treated with $40 \mathrm{nM}$ PB11 for $48 \mathrm{~h}$ and then rinsed with phosphate-buffered saline (PBS) before harvested. Positive control was conducted with $5 \mu \mathrm{M}$ camptothecin. The cells were resuspended in ice-cold lysis buffer $(10 \mathrm{mM}$ Tris [pH 7.5], $0.2 \%$ Triton X-100, and $10 \mathrm{mM}$ EDTA) and incubated on ice for $30 \mathrm{~min}$. The lysates were centrifuged at $10,000 \times g$ at $4{ }^{\circ} \mathrm{C}$ for $10 \mathrm{~min}$, and the supernatants were consecutively extracted with buffered phenol, buffered phenol-chloroform, and chloroform-isoamyl alcohol (24: 1, vol/vol). The DNA was ethanol-precipitated and then resuspended in 
$10 \mathrm{mM}$ Tris (pH 7.5) with $1 \mathrm{mM}$ EDTA, treated with RNase A for $30 \mathrm{~min}$ at $37^{\circ} \mathrm{C}$, and then analyzed via electrophoresis on a $1.5 \%$ agarose gel.

\subsubsection{Evaluation of Nuclear Morphology}

The morphological changes in the nuclei of PB11-treated cells were examined via DAPIstaining, as described previously [32]. Cells were seeded in 8-well plates $\left(1.5 \times 10^{5}\right.$ cells/well $)$ and treated under the same conditions as those used for the MTT assay described above. After $48 \mathrm{~h}$ incubation period, the medium was removed, and the cells were washed three times with PBS. Afterward, the cells were fixed with $4 \%$ formaldehyde with $0.1 \%$ triton $\mathrm{X}-100$ for $20 \mathrm{~min}$ at $25^{\circ} \mathrm{C}$. Next, these fixed cells were stained with $10 \mathrm{mM}$ DAPI in $1 \times$ PBS for $1 \mathrm{~h}$ at $37^{\circ} \mathrm{C}$. The samples were visualized using a Nikon fluorescence microscope (TE $2000 \mathrm{u}$; Tokyo, Japan) with ultraviolet (UV) excitation at the wavelengths between 300 and $500 \mathrm{~nm}$.

\subsubsection{Caspase Activity Assay}

The caspase- $3,-8$, and -9 activities were measured using the caspase- $-3,-8$, and -9 colorimetric assay kits (Promega, Biovision, USA), respectively [32,34]. U87 and HeLa cells were treated with $40 \mathrm{nM}$ PB11 for 0,24 , or $48 \mathrm{~h}$. Then, $50 \mu \mathrm{L}$ of the cell-lysis buffer was added to the cells, and the samples were incubated for $10 \mathrm{~min}$ on ice. Subsequently, the samples were centrifuged at $10,000 \times g$ for $1 \mathrm{~min}$, and the total protein concentration of each supernatant was quantified by Bradford assay. Afterward, each lysate of $20 \mu \mathrm{g}$ total protein was mixed with $50 \mu \mathrm{L}$ of $2 \times$ reaction buffer and $4 \mathrm{mM}$ DEVD-pNA substrate or $4 \mathrm{mM}$ LEHD-pNA substrate from assay kits. After incubating for $1 \mathrm{~h}$ at $37^{\circ} \mathrm{C}$, the absorbance of the samples at $405 \mathrm{~nm}$ was measured using a spectrophotometer.

\subsection{Western Blotting Analysis}

Cells were seeded in 6-well plates $\left(2.0 \times 10^{5}\right.$ cells/well). After $24 \mathrm{~h}$, the cells were treated with $40 \mathrm{nM}$ PB11. Untreated and treated cells were lysed in RIPA buffer (50 Mm Tris- $\mathrm{HCl}$ [pH 7.4], $0.1 \%$ SDS, $0.5 \%$ sodium deoxycholate, and $150 \mathrm{mM} \mathrm{NaCl}$ ). The lysates were centrifuged at $20,000 \times g$ for $15 \mathrm{~min}$ at $4{ }^{\circ} \mathrm{C}$. Total-protein concentration was measured using the Bradford assay. Blotting was conducted as previously reported [33]. Briefly, the proteins of each lysate (equivalent of $10 \mu \mathrm{g}$ total protein) were resolved via SDS-PAGE at $130 \mathrm{~V}$ for $1.5 \mathrm{~h}$. The resolved proteins were then transferred onto nitrocellulose membranes (GE Healthcare UK Ltd., Hammersmith, UK) at $40 \mathrm{~V}$ for $1.5 \mathrm{~h}$ via a semi-dry-transfer apparatus (Hoefer, Inc., Holliston, MA, USA). The membranes were blocked for $3 \mathrm{~h}$ at $25{ }^{\circ} \mathrm{C}$ with the blocking buffer PBST $(5 \%[w / v]$ non-fat dry milk and $0.1 \%[w / v]$ Tween 20 in PBS]. Finally, the membranes were then probed with the appropriate monoclonal antibodies against apoptosis-associated proteins (1:1000 dilution) in PBST solution for $1 \mathrm{~h}$. After washing with PBST, the membranes were incubated with goat anti-rabbit IgG conjugated to horseradish peroxidase (1:10,000 dilution, Sigma-Aldrich, USA) or goat anti-mouse IgG conjugated to horseradish peroxidase (1:5000 dilution, Abcam, Cambridge, UK) in PBST for $1 \mathrm{~h}$ at room temperature. The membranes were washed three times with PBST and developed with a chemiluminescence detection kit (BioFACT, Daejeon, Korea). As an internal control, $\beta$-actin was probed with a mouse monoclonal antibody (1:5000 dilution, Thermo Fisher Scientific, Waltham, MA, USA).

\subsection{Statistical Analysis}

All data are expressed as mean \pm SEM. Statistical significance was analyzed with the two-paired Student's $t$-test; ${ }^{*}=p<0.05,{ }^{* *}=p<0.01$, and ${ }^{* * *}=p<0.001$.

\section{Conclusions}

In this study, the results suggest that PB11 is highly cytotoxic to cancer cells because it induces apoptosis by suppressing the PI3K/AKT signaling pathway. 
Author Contributions: Conceptualization, S.H.H.; investigation, S.H.J.; data analysis and writing the original draft, J.K.; data curation and visualization, M.H.P.; manuscript revision, project administration, and funding acquisition, C.-G.S. All authors have read and agreed to the published version of the manuscript.

Funding: This research was supported by a grant from the National Research Foundation of Korea (NRF) funded by the Korean government (NRF-2018R1D1A1A09081872) to Cha-Gyun Shin.

Institutional Review Board Statement: Not applicable.

Informed Consent Statement: Not applicable.

Data Availability Statement: The data that support the findings of this study are available from the corresponding author upon reasonable request.

Conflicts of Interest: The authors declare no conflict of interest.

\section{References}

1. Palucka, A.K.; Coussens, L.M. The basis of oncoimmunology. Cell 2016, 164, 1233-1247. [CrossRef]

2. Vacchelli, E.; Bloy, N.; Aranda, F.; Buqué, A.; Cremer, I.; Demaria, S.; Eggermont, A.; Formenti, S.C.; Fridman, W.H.; Fucikova, J.; et al. Trial watch: Immunotherapy plus radiation therapy for oncological indications. Oncoimmunology 2016, 5, e1214790. [CrossRef] [PubMed]

3. DeNardo, D.G.; Brennan, D.J.; Rexhepaj, E.; Ruffell, B.; Shiao, S.L.; Madden, S.F.; Gallagher, W.M.; Wadhwani, N.; Keil, S.D.; Junaid, S.A.; et al. Leukocyte complexity predicts breast cancer survival and functionally regulates response to chemotherapy. Cancer Discov. 2011, 1, 54-67. [CrossRef] [PubMed]

4. Mohanty, R.; Chowdhury, C.R.; Arega, S.; Sen, P.; Ganguly, P.; Ganguly, N. CAR T cell therapy: A new era for cancer treatment (Review). Oncol. Rep. 2019, 42, 2183-2195. [CrossRef] [PubMed]

5. Wiemann, M.C.; Calabresi, P. Principles of current cancer chemotherapy. Compr. Ther. 1983, 9, 46-52. [PubMed]

6. Makin, G. Targeting apoptosis in cancer chemotherapy. Expert. Opin. Ther. Targets 2002, 6, 73-84. [CrossRef]

7. Choo, Z.; Loh, A.; Chen, Z.X. Destined to Die: Apoptosis and Pediatric Cancers. Cancers 2019, 11, 1623. [CrossRef] [PubMed]

8. Irfan, A.; Batool, F.; Naqvi, S.A.Z.; Islam, A.; Osman, S.M.; Nocentini, A.; Alissa, S.A.; Supuran, C.T. Benzothiazole derivatives as anticancer agents. J. Enz. Inhib. Med. Chem. 2020, 35, 265-279. [CrossRef]

9. Akhtar, J.; Khan, A.A.; Ali, Z. Structure-activity relationship (SAR) study and design strategies of nitrogen-containing heterocyclic moieties for their anticancer activities. Eur. J. Med. Chem. 2017, 5, 143-189. [CrossRef] [PubMed]

10. Mats, M.E.; Shani, B.G.; Pasternak, L.; Uritsky, N.; Getter, T.; Viskind, O.; Eckel, J.; Cerasi, E.; Senderowitz, H.; Sasson, S.; et al. Synthesis and mechanism of hypoglycemic activity of benzothiazole derivatives. J. Med. Chem. 2013, 56, 5335-5350. [CrossRef]

11. Padalkar, S.V.; Gupta, D.V.; Phatangare, R.K.; Patil, V.S.; Sekar, U.N. Synthesis of novel dipodal-benzimidazole, benzoxazole and benzothiazole from cyanuric chloride: Structural, photophysical and antimicrobial studies. J. Saudi Chem. Soc. 2014, 18, 262-268. [CrossRef]

12. Venkatesh, P.; Pandeya, N.S. Synthesis, characterization and anti-inflammatory activity of some 2-amino benzothiazole derivatives. Int. J. Chem. Tech. Res. 2009, 1, 1354-1358.

13. Liu, Y.; Wang, Y.; Dong, G.; Zhang, Y.; Wu, S.; Miao, Z.; Yao, J.; Zhang, W.; Sheng, C. Novel benzothiazole derivatives with a broad antifungal spectrum: Design, synthesis and structure-activity relationships. Med. Chem. Commun. 2013, 4, 1551-1561. [CrossRef]

14. Hutchinson, I.; Bradshaw, T.D.; Matthews, C.S.; Stevens, M.F.G.; Westwell, A.D. Antitumour benzothiazoles. Part 20: $3^{\prime}$-cyano and $3^{\prime}$-alkynyl-substituted 2-(4'-aminophenyl) benzothiazoles as new potent and selective analogues. Bioorg. Med. Chem. Lett. 2003, 13, 471-474. [CrossRef]

15. Cai, J.; Sun, M.; Wu, X.; Chen, J.; Wang, P.; Zong, X.; Ji, M. Design and synthesis of novel 4-benzothiazole amino quinazolines Dasatinib derivatives as potential anti-tumor agents. Eur. J. Med. Chem. 2013, 63, 702-712. [CrossRef] [PubMed]

16. Hegde, M.; Vartak, S.V.; Kavitha, C.V.; Ananda, H.; Prasanna, D.S.; Gopalakrishnan, V.; Choudhary, B.; Rangappa, K.S.; Raghavan, S.C. A Benzothiazole Derivative (5g) Induces DNA Damage and Potent G2/M Arrest in Cancer Cells. Sci. Rep. 2017, 7, 2533. [CrossRef]

17. Rodrigues, J.R.; Charris, J.; Camacho, J.; Barazarte, A.; Gamboa, N.; Antunes, F. Cytotoxic effects of N'-formyl-2-(5-nitrothiophen2-yl) benzothiazole-6-carbohydrazide in human breast tumor cells by induction of oxidative stress. Antican. Res. 2012, 32, 2721-2726.

18. Xia, Y.; Lei, Q.; Zhu, Y.; Ye, T.; Wang, N.; Li, G.; Shi, X.; Liu, Y.; Shao, B.; Yin, T.; et al. SKLB316, a novel small-molecule inhibitor of cell-cycle progression, induces G2/M phase arrest and apoptosis in vitro and inhibits tumor growth in vivo. Cancer Lett. 2014, 355, 297-309. [CrossRef] [PubMed]

19. Osmaniye, D.; Levent, S.; Karaduman, A.B.; Ilgın, S.; Özkay, Y.; Kaplancıklı, Z.A. Synthesis of new benzothiazole acylhydrazones as anticancer agents. Molecules 2018, 23, 1054. [CrossRef] [PubMed]

20. Kim, T.W.; Hong, D.W.; Park, J.W.; Hong, S.H. CB11, a novel purine-based PPAR $\gamma$ ligand, overcomes radio-resistance by regulating ATM signalling and EMT in human non-small-cell lung cancer cells. Br. J. Cancer 2020, 123, 1737-1748. [CrossRef] 
21. Kim, T.W.; Hong, D.W.; Kang, C.M.; Hong, S.H. A novel PPAR $\gamma$ ligand, PPZ023, overcomes radioresistance via ER stress and cell death in human non-small-cell lung cancer cells. Exp. Mol. Med. 2020, 52, 1730-1743. [CrossRef] [PubMed]

22. Kim, T.W.; Hong, D.W.; Hong, S.H. CB13, a novel PPAR $\gamma$ ligand, overcomes radio-resistance via ROS generation and ER stress in human non-small cell lung cancer. Cell Death Dis. 2020, 11, 848. [CrossRef] [PubMed]

23. Smith, S.M.; Wunder, M.B.; Norris, D.A.; Shellman, Y.G. A simple protocol for using a LDH-based cytotoxicity assay to assess the effects of death and growth inhibition at the same time. PLoS ONE 2011, 6, e26908. [CrossRef] [PubMed]

24. Liu, L.F.; Dauann, P.; Lin, C.T.; D'Arpa, P.; Wu, J. Mechanism of action of Camptothecin. Ann. N. Y. Acad. Sci. 1996, 803, 44-49. [CrossRef] [PubMed]

25. Thomberry, N.A. Caspase: A decade of death research. Cell Death Differ. 1999, 6, 1023-1027. [CrossRef]

26. Chang, F.; Lee, J.T.; Navolanic, P.M.; Steelman, L.S.; Shelton, J.G.; Blalock, W.L.; Franklin, R.A.; McCubrey, J.A. Involvement of PI3K/AKT pathway in cell cycle progression, apoptosis, and neoplastic transformation: A target for cancer chemotherapy. Leukemia 2003, 17, 590-603. [CrossRef]

27. Zeke, A.; Misheva, M.; Remenyi, A.; Bogoyevitch, M. JNK signaling: Regulation and functions based on complex protein-protein partnerships. Microbiol. Mol. Biol. Rev. 2016, 80, 793-835. [CrossRef] [PubMed]

28. Liu, T.; Zhang, L.; Joo, D.; Sun, S. NF-кB signaling in inflammation. Sign. Transducer Target. Ther. 2017, 2, e17023. [CrossRef] [PubMed]

29. Yoshida, M.; Hayakawa, I.; Hayashi, N.; Agatsuma, T.; Oda, Y.; Tanzawa, F.; Iwasaki, S.; Koyama, K.; Furukawa, H.; Kurakata, S.; et al. Synthesis and biological evaluation of benzothiazole derivatives as potent antitumor agents. Bioorg. Med. Chem. Lett. 2005, 15, 3328-3332. [CrossRef] [PubMed]

30. Cindrić, M.; Perić, M.; Kralj, M.; Martin-Kleiner, I.; David-Cordonnier, M.H.; Paljetak, H.Č.; Matijašić, M.; Verbanac, D.; KarminskiZamola, G.; Hranjec, M. Antibacterial and antiproliferative activity of novel 2-benzimidazolyl- and 2-benzothiazolyl-substituted benzo[b]thieno-2-carboxamides. Mol. Divers. 2018, 22, 637-646. [CrossRef]

31. Hennessy, B.T.; Smith, D.L.; Ram, P.T.; Lu, Y.; Mills, G.B. Exploiting the PI3K/AKT pathway for cancer drug discovery. Nat. Rev. Drug Discov. 2005, 4, 988-1004. [CrossRef] [PubMed]

32. Hossain, M.A.; Wongsrikaew, N.; Yoo, G.W.; Han, J.; Shin, C.G. Cytotoxic effects of polymethoxyflavones isolated from Kaempferia parviflora. J. Korean Soc. Appl. Biol. Chem. 2012, 55, 471-476. [CrossRef]

33. Lee, G.E.; Shin, C.G. Influence of pretreatment with immunosuppressive drugs on viral proliferation. J. Microbiol. Biotechnol. 2018, 28, 1716-1722. [CrossRef] [PubMed]

34. Hyun, U.; Lee, D.H.; Lee, C.; Shin, C.G. Apoptosis induced by enniatins H and MK1688 isolated from Fusarium oxysporum FB1501. Toxicon 2009, 53, 723-728. [CrossRef] 